
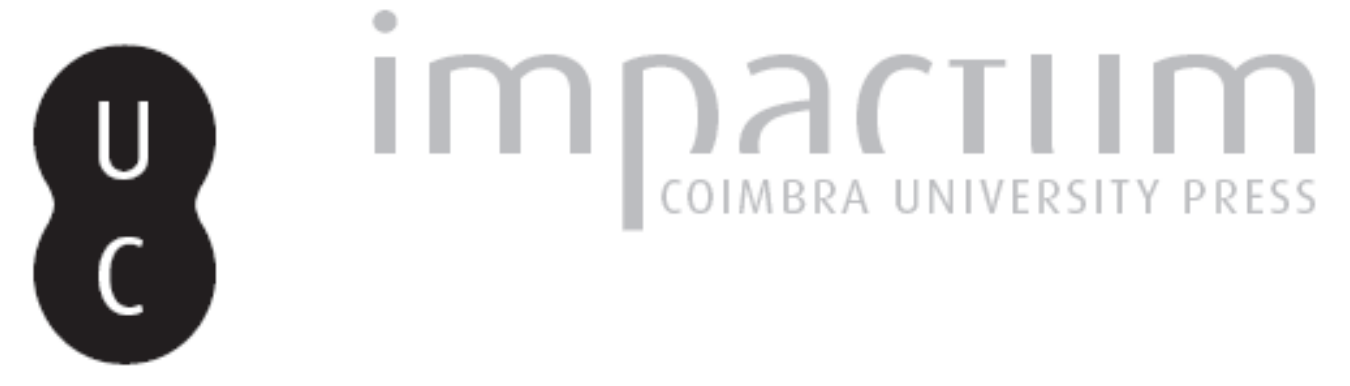

\title{
A freguesia de Turquel (Alcobaça): alguns dados arqueológicos
}

Autor(es): Bettencourt, Ana M. S.

Publicado por: Imprensa da Universidade de Coimbra

URL persistente:

URl:http://hdl.handle.net/10316.2/45587

DOI:

DOI:https://dx.doi.org/10.14195/1647-8657_27_4

Accessed : $\quad$ 26-Apr-2023 12:00:54

A navegação consulta e descarregamento dos títulos inseridos nas Bibliotecas Digitais UC Digitalis, UC Pombalina e UC Impactum, pressupõem a aceitação plena e sem reservas dos Termos e Condições de Uso destas Bibliotecas Digitais, disponíveis em https://digitalis.uc.pt/pt-pt/termos.

Conforme exposto nos referidos Termos e Condições de Uso, o descarregamento de títulos de acesso restrito requer uma licença válida de autorização devendo o utilizador aceder ao(s) documento(s) a partir de um endereço de IP da instituição detentora da supramencionada licença.

Ao utilizador é apenas permitido o descarregamento para uso pessoal, pelo que o emprego do(s) título(s) descarregado(s) para outro fim, designadamente comercial, carece de autorização do respetivo autor ou editor da obra.

Na medida em que todas as obras da UC Digitalis se encontram protegidas pelo Código do Direito de Autor e Direitos Conexos e demais legislação aplicável, toda a cópia, parcial ou total, deste documento, nos casos em que é legalmente admitida, deverá conter ou fazer-se acompanhar por este aviso.

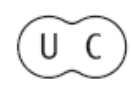


FACULDADE DE LETRAS

INSTITUTO DE ARQUEOLOGIA

\title{
CONIMBRIGA
}

\author{
VOLUME XXVII
}

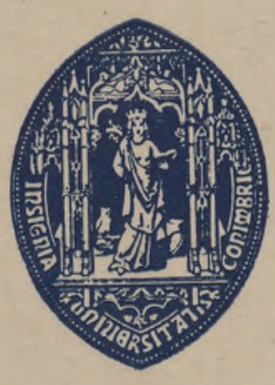

UNIVERSIDADE DE COIMBRA

1988 
ANA M. S. BETtencourt

Assistente da Universidade do Minho

A FREGUESIA DE TURQUEL (ALCOBAÇA)

ALGUNS DADOS ARQUEOLÓGICOS

«Conimbriga» XXYII (1988) p. 153-188

RESUM O: A autora participou num projecto de levantamento da carta arqueológica do concelho de Alcobaça e explorou particularmente a Freguesia de Turquel. Apresenta aqui o inventário das estações pré-históricas e romanas que conseguiu identificar naquela freguesia.

RÉSUMÉ: L'auteur a participe dans les travaux d'élaboration de la carte archéologique du «concelho» d'Alcobaça et a été chargée de la paroisse de Turquel. Elle présente ici l'inventaire des sites pré-historiques et romains qui ont été identifiés dans les limites de la dite paroisse 
(Página deixada propositadamente em branco) 


\section{A FREGUESIA DE TURQUEL (ALCOBAÇA) ALGUNS DADOS ARQUEOLÓGICOS}

\section{Introdução}

Em 1982, e sob a orientação do Prof. Doutor Jorge de Alarcão, fomos convidados a participar na elaboração da Carta Arqueológica dos «Coutos de Alcobaça», trabalho este que se inseria no âmbito de um projecto museológico (1).

Por razões várias, independentes da nossa vontade, vimo-nos impossibilitados de continuar este projecto. Resolvemos, por isso, publicar alguns dados disponíveis, resultantes da prospecção e da pesquisa bibliográfica que então efectuamos.

As informações recolhidas são essencialmente da freguesia de Turquel. Apesar das limitações que uma «fronteira» adminis-

(1) Este trabalho, financiado pelo Instituto Português do Património Cultural e patrocinado pela Comissão para a Instalação do Museu dos Coutos de Alcobaça, tinha como objectivo a elaboração da Carta Arqueológica dessa região. Participaram no projecto vários investigadores, distribuindo-se por períodos cronológicos diferentes, ficando a signatária deste artigo responsável pela Pré e Proto-História. Não deixámos, porém, de referenciar toda e quaquer informação relativa a épocas posteriores e obtida no decurso da nossa investigação. Queremos agradecer particularmente ao Doutor Jorge de Alarcão e à Doutora Susana Oliveira Jorge, a orientação prestada durante a elaboração deste trabalho; aos Doutores Veiga Ferreira e Georges Zbyszewsky, as facilidades concedidas no Museu dos Serviços Geológicos de Portugal; aos familiares de José Diogo Ribeiro, a amável cedência da bibliografia do autor; e à população de Turquel, toda a sua simpatia e ajuda no trabalho de campo. 
trativa representa num trabalho deste tipo, não quisemos deixar de transmitir algumas observações que consideramos necessárias para quem venha a trabalhar sobre a região $\left(^{2}\right)$.

\section{Meio físico}

Turquel é uma das 13 freguesias de Alcobaça. Situa-se na parte meridional do concelho e ocupa uma área de cerca de $40 \mathrm{~km}^{2}$.

Compreende os seguintes lugares: Ardido, Baldio, Beijinha, Cabeço do Seixo, Cancela, Carvalhal, Casal do Álvaro, Casal de Baixo, Casal dos Gaiteiros, Casal da Lagoa, Casal do Moniz, Casal dos Tintas, Casal de Val de Ventos, Chão do Galego, Charneca do Rio Seco, Covão do Milho, Eiras, Feitosa, Frazões, Lagoa das Talas, Lombo, Louções, Matinho, Moita do Poço, Mouzinha, Orjo, Pedra Redonda, Pinheiro, Poço das Vinhas, Portela do Pereiro, Redondas, Silvai e Zambujeira.

Tendo como ponto de referência o próprio lugar de Turquel, verificamos que a região oriental é ocupada, grosso modo, pela encosta da serra dos Candeeiros e por um grande vale que se situa entre o sopé da serra e a colina onde assenta a povoação de Turquel.

A oeste, surgem novas colinas recortadas por inúmeros vales onde uma rede hidrográfica abundante se espalha.

A serra dos Candeeiros, formada por uma dobra anticlinal e orientada no sentido NNE-SSW, faz parte do Maciço Calcário Estremenho. Os seus calcários datam do Jurássico superior e médio, assim como os afloramentos do vale. As brechas calcárias frequentes na encosta ocidental da serra são atribuídas ao Plioceno superior ou ao Vilafranquiano. Os bancos de argila margosa desta mesma encosta pertencem ao Jurássico médio ou Dogger.

A paisagem apresenta as características de um «Karst» clássico, árido, seco e pobre de vegetação. Inúmeras grutas e algares

(2) Foi apresentado um relatório circunstanciado sobre a área estudada, à Comissão para a Instalação do Museu dos Coutos de Alcobaça. 
abrem-se em toda a região, resultantes da grande infiltração das águas das chuvas e da intensa circulação subterrânea das mesmas.

O grande vale do sopé da serra segue a orientação desta e é constituído por cambissolos crómicos com algumas potencialidades agrícolas (3).

Nas colinas a oeste de Turquel, a parte superior do Jurássico é constituída por grés e argilas de cores diversas, conhecidos pela designação de "grés superiores com vegetais e dinossáurios» $\left.{ }^{4}\right)$. $\mathrm{Na}$ região, as principais linha de água têm formações aluvionares modernas, como é o caso do rio Seco, da ribeira das Antas e da ribeira das Vinhas. No Cabeço do Seixo, extremo ocidental da freguesia, aparecem terrenos plio-plistocénicos, o chamado «complexo astiano de Nadadoiro e Águas Santas»e as «camadas vilafranquianas com tignitos e diatomitos de Rio Maior, Óbidos, etc.» $\left({ }^{4}\right)$.

Com excepção da zona «kársica» da serra, a flora primitiva mais comum seria constituída por florestas de carvalhos cerquinhos (Quercus Jaginea Lam.) ( ${ }^{5}$ ).

\section{Metodologia}

Seguimos a metodologia usual, pelo que faremos apenas uma breve descrição:

- Fizemos a recolha bibliográfica do concelho de Alcobaça, a partir da qual elaborámos fichas provisórias por estação e por achado arqueológico isolado.

- Seguindo as indicações bibliográficas, identificámos no terreno as estações citadas e o local de proveniência dos achados isolados, cartografando-os na C.M.P.,esc. 1:25.000, descrevendo-os e verificando as suas condições actuais de conservação; deste modo, as rubricas (lugar, localização

$\left({ }^{3}\right)$ Segundo a Carta dos Solos de Portugal, esc. 1:1000.000, visto não estar publicada a Carta dos Solos de Alcobaça na esc. 1:50.000.

$\left({ }^{4}\right)$ Segundo a Carta Geológica de Portugal esc. 1:50.000, folha 26-D, Caldas da Rainha e respectiva notícia explicativa.

(6) Segundo Carlos da Silva; Alberto Eduardo N. L. A. e Silva, 1961. 
geográfica e geomorfologia) são inteiramente da nossa responsabilidade.

- Esgotadas as pistas bibliográficas, debruçámo-nos sobre a toponímia do concelho, prospectando todas as áreas cujos topónimos sugeriam locais com interesse arqueológico.

- Foram também prospectadas zonas ou micro-zonas cujas condições geomorfológicas nos pareceram propícias ao povoamento humano.

- Não desprezámos as informações orais dadas pela população local, informações que verificámos no terreno sempre que nos pareceu oportuno.

- Procurámos o paradeiro do espólio arqueológico proveniente de antigas escavações e dos achados isolados.

- Utilizámos várias cartas, entre as quais : Carta Militar de Portugal, esc. 1:25.000; Carta Corogràfica de Portugal, esc. 1:50.000; Carta Geológica de Portugal, esc. 1:50.000; Mapa Geomorfológico de Portugal, esc. 1:500.000; Carta dos Solos de Portugal, esc. 1:1.000.000.

- As fichas utilizadas foram as propostas pelo Instituto de Arqueologia da Faculdade de Letras da Universidade de Coimbra à data da realização dos trabalhos, embora aqui se representem simplificadas.

- Apesar do grau de destruição de grande número de estações, tentámos descrevê-las baseando-nos nas fontes bibliográficas de que dispúnhamos.

- A descrição do espólio levantou algumas dificuldades: recorremos de igual modo à bibliografia, actualizando a terminologia sempre que nos pareceu oportuno.

- Procurámos ordenar as fichas cronologicamente, tendo como objectivo tirar conclusões de âmbito mais alargado. As classificações cronológicas das estações conhecidas foram revistas por nós, algumas vezes modificadas, outras corroboradas, sempre com algumas reservas devido às dificuldades apontadas nas alíneas anteriores.

- Nas estações inéditas, evidentemente, todas as rubricas são da nossa responsabilidade.

- Em cada ficha, a bibliografia vem citada por ordem cronológica. 
ABREVIATURAS:

- Tipo de Est.

- Cl. Cron.

- Lug.

- Loe. Geog.

- Geomorf.

- Esc.

- Desc. da Est.

- Desc. do Mon.

- Esp.

- Dep.

- Bib.

- C.M. P.
Tipo de Estação

Classificação Cronológica

Lugar

Localização Geográfica

Geomorfologia

Escavações

Descrição da Estação

Descrição do Monumento

Espólio

Depósito

Bibliografia

Carta Militar de Portugal

\section{Estações arqueológicas}

\subsection{PALEOLítico}

\subsubsection{Cabeço do Seixo}

Tipo de Est. - Cascalheira.

Cl. Cron. - Paleolítico inferior ( ?).

Lug. - Cabeço do Seixo.

Loc. Geog. - C. M. P., esc. 1:25.000, 327 Turquel (Alcobaça), M. 125,8; P. 277; Alt. cerca de 236 m. Levantamento de 1931/32 (fig. 1.1).

Geomorf. - No alto de um cabeço calcário do Jurássico superior indiferenciado, com camadas vilafranquianas subjacentes. Zona agrícola e florestal.

Desc. da Est. - Na zona mais elevada do cabeço, na base de um corte feito pelo estradão, do lado esquerdo para quem vem de Frazões e nos terrenos agrícolas adjacentes, encontram-se alguns seixos que parecem afeiçoados.

Esp. $\quad-1$ seixo quartzítico de grão médio afeiçoado unifacialmente. Muito rolado e com patine esbranquiçada (fig. 2). 
3 seixos rolados com afeiçoamento bifacial, formando uma aresta irregular. Muito rolados e com patine esbranquiçada (fig. 3).

Dep. Instituto de Arqueologia da Fac. de Letras da Univ. de Coimbra.

Bib. Inédita.

\subsubsection{Casa da Moura}

Tipo de Est. - - Gruta natural.

Cl. Cron. - Paleolítico (?).

Lug. -Charneca do Rio Seco.

Loc. Geog. -C.M.P., esc. 1:25.000, 327 Turquel (Alcobaça), M. 130,2; P. 276,6; Alt. cerca de 240 m. Levantamento de 1931/32 (fig. 1.2).

Geomorf. -Gruta aberta no calcário do Jurássico superior na vertente NO do Cabeço de Turquel. Zona florestal.

Esc. $\quad-1869$ - Escavações de Joaquim Possidónio da Silva.

- 1881 ( ?) - Escavações de Carlos Ribeiro.

Desc. da Est. - - A entrada, de forma ogival, conduz a uma grande sala de onde parte uma pequena galeria. Tem enchimento. A estratigrafía da gruta é mal conhecida mas depreende-se de A. S. A. B. P. LEAL, 1873 e de J. D. Ribeiro, 1908, que teriam existido quatro níveis distintos:

1 - Depósito recente pouco espesso.

2 - Camada de cinza e ossos (alguns deles já concrecionados) bastante espessa e ocupando todo o centro da gruta.

3 - Camada de areia.

4 - Camada de cinza e ossos semelhantes à segunda.

Os níveis arqueológicos seriam o 2 e o 4 . O espólio foi encontrado a $60 \mathrm{~cm}$ e $150 \mathrm{~cm}$ de profundidade. 
Esp. $\quad$ - Segundo os autores citados anteriormente e urna ficha manuscrita do Museu dos Serviços Geológicos de Portugal, o espolio seria o seguinte:

- Ossadas humanas (?).

- Ossadas de carneiro.

- Chifres de veado.

- Objectos de sílex lascado.

Dep. - Desconhecido.

Bib. - - Augusto S. A. B. de Pinho Le al, p. 46, refere as escavações de Joaquim Possidónio da Silva e diz: «Achou o Sr. Silva, a pouca profundidade, uma camada de cinza (com muitos ossos misturados) de bastante espessura e ocupando todo o centro da gruta. Por baixo desta camada de cinza achou uma de areia e por baixo desta, outra de cinza e ossos, como a superior».

- Manuscrito que se encontra no armário correspondente à vitrina central n. ${ }^{\circ} 34$ da Sala de Arqueologia Pré-Histórica do Museu dos Serviços Geológicos de Portugal (Lisboa): «Apareceram em 16/07/80 ossadas de carneiro à profundidade de $1,50 \mathrm{~m}$ e chifres de veado e bocados de silex lascado à profundidade de $0,60 \mathrm{~m}$ ».

Comentário :

Presumimos que a data diz respeito ao ano de 1880. Não conseguimos localizar este espólio.

- A. Mesquita de Figueiredo, 1895, p. 154, refere esta gruta.

- José Diogo Ribeiro, 1908, p. 10 e 11, localiza esta gruta e refere o seu espólio.

- José Diogo Ribeiro, 1927, p. 25 e 27, refere duas lendas associadas a este local.

\subsubsection{Algar do João Ramos ou gruta das Redondas}

Tipo de Est. - Gruta natural.

Cl. Cron. - Paleolítico médio/superior ( ?). 
Lug. - Covão do Milho (Redondas).

Loe. Geog. - C.M.P., esc. 1:25.000, 327 Turquel (Alcobaça), M. 131; P. 279,5; Alt. 190 m. Levantamento de 1931/32 (fig. 1.3).

Geomorf. - Gruta aberta no calcário do Jurássico, na base da encosta ocidental da serra dos Candeeiros. Zona agrícola.

Esc. $\quad-1890$ ( ?) — Escavações de Manuel Vieira Natividade.

— Escavações dos Serviços Geológicos de Portugal.

Desc. da Est. - A entrada actual da gruta faz-se por um algar subvertical de cerca de $6 \mathrm{~m}$ de comprimento que dá acesso a diversas galerias. A estratigrafía da gruta é mal conhecida mas parece depreender-se de M. V. Natividade, 1899/1903, que existiam dois níveis bem distintos:

1 - Depósito recente de pequena espessura com uma média de $20 \mathrm{~cm}$.

2 - Espesso manto de estalagmite terrosa alternada com grossa camada de argila. Seria este o nível paleolítico.

Esp.

-Segundo E. Harlé, 1910/1911 ; G. Zbyszewsky, 1943; O. da V. Ferreira, 1964 e 1982.

- Litico: raspadores, lâminas e lascas em quantidade que não foi possível determinar.

- Osteológico: brecha ossifera, Hyaena striata, Meles taxus, Canis lupus, Felis par dina, Equus caballus, Grande Bos, Cervus elaphus, Lepus timidus, Lepus cuniculus, Ovis ( ?), uma arcada sigmoidea de urso e um fragmento de fémur de Elaphus antiquus com incisões profundas, mostrando uma fauna de clima temperado.

Dep. - - Sala de Arqueologia Pré-Histórica do Museu dos Serviços Geológicos de Portugal (Lisboa). 
Bib.

- Manuel Vieira Natividade, 1899/1903, p. 456, descreve a estratigrafía da gruta: «Notei desde os primeiros trabalhos que o depósito recente era de pequena espessura, tendo, em média vinte centímetros, e por vezes assentava sobre um espesso manto de estalagmite terrosa, alternada e com predomínio de grossa camada de argila ferroginosa, que pertence, segundo suponho, a edades geológicas».

Mais adiante, na p. 457, continua: «Protegido pelo depósito que explorei, e em parte pelo manto estalagmítico, existe, segundo creio, um grande depósito quaternário».

$\mathrm{O}$ que nos faz pensar que todas as ossadas encontradas posteriormente pertencem ao segundo nível estratigráfico, é uma afirmação do autor na p. 456 que se refere ao depósito recente: «Não achei ossos de animais que indiquem a espécie de alimentação do homem das Redondas»».

- Edouard Harlé, 1910/1911, p. 50 e 51, estuda o espólio osteológico da campanha arqueológica de 1909 , e afirma que nenhuma das ossadas pode ser atribuída com segurança ao quaternário, devido à situação meridional do país, onde os animais de clima frio do Norte dos Pirenéus não aparecem. Mostra fotografias.

- Georges Zвyszewsky, 1943, p. 77 e 78, refere a propósito de um fragmento ósseo identificado por E. HARLÉ, ob. cit., como de rinoceronte: «II s'agit pour nous d'un fragment de fémur de jeune Eléphant, car la nature et la constitution de l'os, nous le font écarter des ossements de Rhinoceros.

Ses dimensions sont les suivantes:

- Longueur maximum conservée $405 \mathrm{~mm}$.

- Largeur maximum conservée (antéro-postérieure) $111 \mathrm{~mm}$. 
— Dimension transverse au même point $76 \mathrm{~mm}$. Cet os est bien fossilisé. Il est fortement tailladé par des outils tranchants, silex ou quartzites. Sa section est ovale pointue.

Aucune industrie antérieure au Paléolithique supérieur n'a été recueillie dans cette grotte. Peut-être, en dehors des belles pièces, n'a-t-on point recueilli les éclats provenant de la taille. Parmi ceux-ci il aurait pu y avoir quelques silex d'âge plus ancien ( ?)». Apresenta várias fotografias.

- Octávio da Veiga Ferreira, 1964, refere nas p. 43 e 44, fauna quaternária nesta gruta e tal como G. ZвYSZEWSKY, ob. cit., afirma sem qualquer explicação que: «Não foi encontrada qualquer indústria anterior ao paleolítico superior». Na p. 53, o autor fala dos níveis estratigráficos em que aparecem vestígios do Quaternário em Portugal: «No estudo das grutas com nível quaternário em Portugal há uma indicação precisa; em todas elas o nível com restos de vertebrados é sempre um depósito avermelhado com calhaus, cinzas, carvões, etc., fazendo uma espécie de brecha ossifera de relativa dureza».

- Octávio da Veiga Ferreira, 1982, p. 32, descreve a fauna e a indústria litica das Redondas guardadas no armário lateral n. ${ }^{\circ}$ 54: «Indústrias do Mustierense e do Paleolítico superior com raspadores, lâminas e lascas»».

Comentário: Observado o material litico desse armário, verificámos que as peças expostas estavam etiquetadas como pertencentes à Gruta da Serra dos Molíanos.

Parece-nos que se trata de um erro de identificação, pois nas duas edições do Guia Descritivo da Sala de Arqueologia Pré-Histórica, 1977 e 1982, não há referências a espólio litico da Gruta da Serra dos Molíanos neste museu. 


\subsection{NEOLÍTICO}

\subsubsection{Buraca do Moniz}

Tipo de Est. - Gruta natural.

Cl. Cron. - Neolítico ( ?).

Lug. - Casal do Moniz.

Loe. Geog. - C.M.P., esc. 1:25.000, 327 Turquel (Alcobaça), M. 127,3; P. 276,40, Alt. 230 m. Levantamento de $1931 / 32$ (fig. 1.4).

Geomorf. - Na encosta sudeste dos Cabeços Ralos ou Cabeça Rala, no calcário do Jurássico superior. Zona agrícola.

Esc. $\quad$ - 1909 - Escavação de Paul Choffat.

Dése, da Est. - Segundo J. D. Ribeiro, 1908, a gruta teria uma entrada subvertical dando acesso a urna ampia galeria de onde partiam várias ramificações num total de 70 e tal metros. Este autor refere a primeira galeria do lado Sul como sendo uma das zonas onde apareceu espólio.

Actualmente, o acesso desta cavidade faz-se por uma entrada artificial. Tem várias galerias de grandes dimensões que foram esvaziadas do seu enchimento inicial, caiadas e cimentadas quando a gruta serviu como viveiro de cogumelos.

Em certos locais, o enchimento atingia mais de $2 \mathrm{~m}$ de profundidade, como se pode observar pelas marcas deixadas nas paredes. As únicas galerias que não foram sujeitas a grandes alterações são pequenos corredores de difícil acesso.

Esp. $\quad-$ Paul Ghoffat encontrou ossos humanos e animais (de cabra e veado); grande quantidade de conchas de amêijoa e berbigão, 1 lâmina de sílex, 1 vaso de barro com cerca de $8 \mathrm{~cm}$ de altura por $12 \mathrm{~cm}$ de diâmetro.

Segundo informação oral de Joaquim Elias Honorio, apareceram em grande quantidade 
restos de ossos, recipientes de barro e conchas, aquando da desobstrução da gruta para viveiro de cogumelos.

Dep. - Uma parte indefinida dos objectos recolhidos por Paul Choffat foi depositada na Museu Vieira Natividade (Alcobaça).

Bib. - José Diogo Ribeiro, p. 18 e 17, descreve esta gruta e o seu espólio. «(...) A Buraca do Moniz, descoberta casualmente ao removerem-se ali umas pedras em Dezembro de 1906, foi indubitavelmente conhecida dos antigos, como o testemunham um montão de conchas marinhas e alguns ossos que se topam na primeira galeria lateral do lado Sul, hoje quasi impraticável, e as stalactites quebradas que nella appareceram e sobre cujos troncos novas stalactites se haviam já implantado».

- J. D. Ribeiro, 1930, p. 10, diz que a gruta foi explorada em Novembro de 1909 por Paul Choffat, que descobriu nova galeria e encontrou ossos humanos, bastantes de cabra e veado, grande quantidade de conchas de amêijoas, berbigão e outras, uma faca de sílex, um vaso de barro com um pouco mais de $8 \mathrm{~cm}$ de altura e cerca de 12 de diâmetro. É aqui que se refere que parte destes objectos foi depositada no Museu Vieira Natividade (Alcobaça).

\subsubsection{Algar do Estreito ou gruta do Carvalhal de Turquel}

Tipo de Est. - Gruta natural.

Cl. Cron. - Neolítico final ( ?)/Calcolítico.

Lug. - Lombo (Carvalhal).

Loe. Geog. - C.M.P., esc. 1:25.000, 327 Turquel (Alcobaça), M. 129,7 ; P. 277,9; Alt. 182. Levantamento 1931/32 (fig. 1.5). 
Geomorf. - Gruta que se abre num afloramento calcário do Jurássico superior, já no grande vale situado na base da serra dos Candeeiros. Zona urbanizada.

Esc. - 1881. Escavações de Carlos Ribeiro.

Desc. da Est. - A entrada actual faz-se por um poço subvercical de cerca de $7 \mathrm{~m}$ de profundidade. Segundo J. D. Ribeiro, 1908, a entrada primitiva dava acesso a uma pequena galeria em cujo tecto existiam duas aberturas para o exterior; este compartimento ligava a uma grande galeria de onde partia ainda uma outra de muitos metros. Não se conhecem dados referentes à estratigrafía da estação, mas, pela análise do espólio, K. SPINDLER e O. da V. FERREIRA, 1974, chegaram à conclusão de que existiram dois níveis de ocupação.

Esp. $\quad-\mathrm{O}$ espólio é riquíssimo e diversificado mas, devido à ausência de estratigrafía, foi extremamente difícil classificar todo o material desta gruta. As primeiras dificuldades põem-se logo ao nível da cerâmica, pois é grande o número de vasos de características pouco individualizadas, que podem ter perdurado por um amplo período cronológico. Estão neste caso as formas lobulares e as taças esféricas e semi-esféricas lisas. As ossadas humanas exumadas são também de classificação cronológica difícil.

Através de um estudo comparativo com outras estações arqueológicas, nomeadamente os povoados de Oleias e Vila Nova de S. Pedro, K. SPINDler e O. da V. Ferreira, ob. cil., atribuíram ao Neolítico final/Cobre inicial, embora com algumas reservas, o material que passaremos a descrever. Pelo conjunto desse espólio preferimos inseri-lo num âmbito cronológico mais alargado. 
- Litico:

5 pontas de seta, 6 pontas de lança e 1 punhal, em sílex; 72 láminas, fragmentos de láminas e lamelas também em sílex; 3 lascas e 10 núcleos de quartzo e sílex; 3 machados, 4 enxós, 1 goiva e 1 escopro, de pedra polida; 1 placa de xisto decorada e 1 fragmento de outra aparentemente lisa; 2 vasos globulares de pequenas dimensões, 1 cilindro, várias bolas e 1 placa curva, tudo em calcário.

- Cerâmico:

Alguns vasos e fragmentos de outros, decorados segundo as técnicas de incisão e puncionamento (puncionamento arrastado ?) e um recipiente em forma de zoomorfo. A terminologia aplicada na descrição deste material é da nossa responsabilidade.

- Osteológico:

Furadores, sovelas ( ?), agulhas e contas.

Dep. $\quad$ - Sala de Arqueologia Pré-Histórica do Museu dos Serviços Geológicos de Portugal (Lisboa), vitrinas centrais n. ${ }^{\circ 5} 65,66$, nos armários correspondentes à vitrina $n .^{\circ} 65$ e no armário lateral $n .{ }^{\circ} 20$.

Bib. - Manuel Vieira Natividade, 1885 , p. 39 , refere a descoberta desta gruta pela primeira vez: «Em 1881 foram estas grutas (Casa da Moura e Algar do Estreito) cuidadosamente exploradas por iniciativa (...) do Sr. Carlos Ribeiro, que n'ellas mandou proceder a consideráveis trabalhos de escavação e removimento de terras, em resultado do que se descobriram numa d'ellas (Algar do Estreito) verdadeiras preciosidades archeologico-pré-históricas (...)».

- Emile Cartailhac, 1886, p. 113 e 114, refere o espólio desta gruta e descreve sumariamente o recipiente cerâmico de forma zoomórfica. Apresenta desenhos. 
- José Diogo Ribeiro, 1908, p. 12 a 14, faz a descrição da gruta e refere um pouco mais pormenorizadamente que M. V. NATIVIDAde, ob. cit., o espólio aí encontrado: "Algar Estreito - Abre-se numa pequena eminência no Sueste e a curta distância do Lombo um dos logarejos que forma o conjunto denominado Carvalhal de Turquel (...). Nesta gruta descobriram-se algumas ossadas humanas, - ossos provenientes de animais diversos, - uma figurinha de barro cozido representando uma porca, - vasos da mesma matéria, - muitas lâminas cortantes ou facas, sendo uma de quartzo hyalino (...) machados e outros instrumentos de pedra, como lanças e dardos (...) uma placa triangular, de ardósia, com um buraco junto a um dos ângulos e (...) apresentando (...) triangulosinhos preenchidos de linhas entrecruzadas, - estyletes e outros utensílios perfurantes, de osso (...) que passaram a enriquecer as collecções do museu ethnologico da direcção geral dos trabalhos geodésicos»».

- J. Camarate França, 1950, p. 95 a 98, estuda este recipiente cerâmico e atribui-o à Idade do Bronze. Apresenta duas hipóteses quanto à origem do recipiente: evolução local ou influência mediterrânica oriental nesta região. Dá fotografias.

- Konrad Spindeer e Octávio da Veiga Ferreira, 1974, p. 28 a 76, publicam de forma exaustiva todo o espólio desta gruta e atribuem-lhe dois níveis de ocupação (Neolítico final/Calcolítico inicial e Bronze), baseados fundamentalmente no estudo da cerâmica. Apresentam desenhos.

- Octávio da Veiga Ferreira, 1982, p. 14 e 24, refere este espólio.

Comentário: K. Spindler, O. V. Ferreira, ob. cit., identificaram a gruta do Carvalhal de Turquel com a gruta existente no Cabeço de Turquel. Baseados 
em M. V. NATIVIDAde, ob. cit., em J. D. Ribeiro, $\boldsymbol{o b}$. cit. e em informações orais recolhidas no local, constatámos que existe ali uma inexactidão. A gruta do Cabeço de Turquel é, e foi conhecida por Casa da Moura; apesar de ter sido ocupada na pré-história, revela um espólio bem menos numeroso do que o encontrado no Carvalhal de Turquel ou Algar do Estreito. Ver ficha n. ${ }^{\circ}$ 3.1.2 deste trabalho.

\subsection{MEgALITISMO}

\subsubsection{Mamoas 1 e 2 da Barbata}

Tipo de Est. - Monumentos megalíticos.

Cl. Cron. - Desconhecida.

Lug. - Zambujeira.

Loc. Geog. - C.M.P., esc. 1:25.000, 317 Alcobaça, M. 129, P. 280, 7 ; Alt. 177 m. Levantamento de 1939/40 (fig. 1.6).

Geomorf. - Numa chã agricultada do grande vale de Turquel. Perto afloram calcários do Jurássico superior.

Desc. do Mon. - José Diogo Ribeiro, 1908, refere a mamoa da Barbata que ficaria situada nas Pedras das Antas. Segundo informações orais, teriam existido não uma, mas duas mamoas no local da Barbata, espaçadas entre si cerca de $50 \mathrm{~m}$. Prospectada a micro-região com este nome, a $300 \mathrm{~m}$ a Leste das Pedras das Antas, nada foi detectado. Segundo a mesma fonte oral, os monumentos teriam sido destruídos quando do arroteamento dos terrenos. As coordenadas atrás indicadas são as do local da Barbata.

Esp. - - Parece depreender-se do texto de J. D. Ribeiro, que foram encontrados alguns vasos cerâmicos. 
Dep.

— Desconhecido.

Bib.

—José Diogo Ribeiro, 1908, p. 25 e 26: «Anta da Barbata - Foi desmantelada há muitos anos por uns camponeses que ali fizeram escavações, na esperança de encontrar uma cabra e um cabrito de oiro a que certa lenda se referia. $\mathrm{O}$ que elles em verdade descobriram, segundo declararam, foi uma cavidade que se lhes afigurou um forno, com copeirinhas, aos lados, não constando se attentaram nos restos humanos que ali houveram de jazer. $\mathrm{O}$ sítio em que este megalitho avultava denominam-no ainda hoje Pedras das Antas. Fica ao nordeste e a uns trezentos metros do Lombo Ferreiro».

- José Diogo Ribeiro, 1935, p. 42, diz: «Perto do Lombo Ferreiro existe ainda um grupo de dólmenes, já desprovidos, porém, da respectiva mesa. O sítio conserva o primitivo nome de Pedras das Antas»».

\subsubsection{Mamoas 1 e 2 das Fontes Velas}

Fontes Velas 1 (fig. 4, 1 e 2)

Tipo de Est. - Monumento megalítico.

Cl. Cron. - Desconhecida.

Lug. -Mouzinha (Carvalhal).

Loc. Geog. -C.M.P., esc. 1:25.000, 327 Turquel (Alcobaça), M.128; P.277,5; Alt. 183 m. Levantamento de 1931/32 (fig. 1.7).

Geomorf. - Numa chã agrícola e florestal do vale de Turquel, com alguns afloramentos calcários do Jurássico superior.

Desc. do Mon. - Monumento de câmara simples, com cinco esteios visíveis, três dos quais partidos. $\mathrm{O}$ esteio de cabeceira, que tem a descoberto $1,20 \mathrm{~m}$ de

Conimbriga, 27 (1988), 153-188 
alt., 1,44 de largura e 0,47 $\mathrm{m}$ de espessura, está virado a Oeste. Por detrás deste, existem ainda restos da mamoa. Na zona da câmara, espalhados, podem ver-se ainda restos de ossadas humanas postas à vista aquando da violação do monumento por Joaquim e António Paulino, há cerca de 12 anos, segundo informações orais recolhidas em 1982.

Os esteios são feitos no calcário da região. $\mathrm{O}$ monumento encontra-se coberto de mato e passa-lhe um muro de propriedade por detrás do esteio de cabeceira (fig. 1 e 2).

Esp. - Ossos humanos; fragmentos de tíbias, fémures, omoplatas, crânios e maxilares; 1 lâmina de sílex; 2 fragmentos de outra e 1 fragmento de lasca de sílex retocada.

Dep. - Victor Pedrosa, residente em Alcobaça. Algumas das ossadas foram recolhidas por nós e encontram-se no Instituto de Arqueologia da Fac. de Letras da Universidade de Coimbra.

Bib. - Inédita.

Fontes Velas 2

A cerca de $200 \mathrm{~m}$ para Norte existiu outra mamoa que foi completamente destruída há cerca de 30 anos por Carlos Susano, antigo proprietário do terreno (fig. 1.7). Existem ainda, no local, fragmentos de esteios provenientes da câmara deste monumento.

Esp. $\quad$ - Segundo António Paulino, apareceram ossadas humanas. Um fragmento de lâmina em sílex, retocada, encontrada nos terrenos agrícolas onde a mamoa foi destruída, faria, provavelmente, parte do espólio (fig. 5). 
Dep. $\quad$ - As ossadas perderam-se. O fragmento de lámina encontra-se no Instituto de Arqueologia da Fac. de Letras da Universidade de Coimbra.

Bib. - Inédita.

\subsection{CALCOLİTICO}

\subsubsection{Algar do João Ramos ou Gruta das Redondas}

Tipo de Est. — ver ficha 3.1.3.

Cl. Cron. - Calcolitico final/Bronze inicial.

Lug. - -ver ficha 3.1.3.

Loe. Geog. - -ver ficha 3.1.3 (fig.1.3).

Geomorf. - ver ficha 3.1.3.

Esc. $\quad-1890(?)$ - Escavações de Manuel Vieira Natividade.

Dése, da Est.—ver ficha 3.1.3. O segundo nível de ocupação, ou seja, o nivel calcolitico, teria sido encontrado num depósito com cerca de $20 \mathrm{~cm}$ de espessura média.

Segundo M. Vieira NATIVId ADE, 1899/1903, a escavação iniciou-se na parte mais funda da gruta mas estendeu-se a todo o depósito recente; a matéria vegetal encontrada numa das galerias setentrionais estava associada a grandes vasos cerâmicos.

Esp. - - Segundo M. V. Natividade, 1899/1903; A. do Paço, 1966; V. dos S. Gonçalves, 1978.

\section{- Litico:}

3 «braçais de arqueiro» em xisto (um deles fragmentado nas duas extremidades) ; 1 conta de azeviche (?); 2 machados polidos de xisto e 2 lâminas de sílex.

\section{- Cerâmico:}

2 vasos globulares lisos de média dimensão;

1 vaso subcilíndrico de fundo plano; 1 vaso 
esferoidal de colo estrangulado; 1 grande vaso de forma subovóide, de fundo plano e esboço de carena alta sob o bordo; 2 vasos de fundo esférico e carena média e alta; 1 vaso campaniforme liso e 3 fragmentos de um único ( ?) vaso campaniforme, decorado com incisões formando faixas preenchidas com reticulado, alternadas com linhas paralelas nas quais seriam visíveis vestígios de pasta branca incrustada. A terminologia usada na descrição deste material foi revista por nós.

- Metálico:

1 punhal de rebites; 2 machados planos;

7 estiletes de pequenas dimensões; 10 pontas (algumas de tipo Palmeia) em cobre.

\section{- Osteológico:}

1 botão ou conta e restos humanos muito alterados.

- Matéria vegetal:

Grãos de cevada; 1 fragmento de arista ou barba, 1 base de flor e 1 grão irisado (restos de gordura?).

- Conchifero:

Valvas de pectunculus perfuradas; conchas de pecten, cassis e pectunculus.

Dep. $\quad$ - Museu Manuel Vieira Natividade (Alcobaça).

- Sala de Arqueologia Pré-Histórica do Museu dos Serviços Geológicos de Portugal, no armáiio lateral $n .{ }^{\circ} 11$.

Bib. - Manuel Vieira Natividade, 1899/1903, p. 455 a 457, descreve a escavação que fez nesta gruta e lefere o material exumado: «Iniciada na parte mais funda, a primeira exploração (...)». «Fiz muito cuidadosamente toda a exploração do depósito recente (...). «Numa das galerias N. 
e junto de restos de grandes vasos, incluindo o que vae representado na fig. 177, foi achada uma porção de trigo carbonizado, e outras sementes que infelizmente se perderam». Apresenta desenhos.

- Nils AвËRG, 1921, p. 84, refere a gruta natural das Redondas e descreve o espólio exumado de forma sumária.

- Afonso do Paço, 1966, p. 90 a 92, descreve os vasos campaniformes:

«Campaniforme $\mathrm{n} .{ }^{\circ} 1$ - Trata-se de um recipiente quasi completo, desprovido de qualquer ornamentação mas de certa elegância, medindo de diâmetro de boca 12 centímetros e de altura 9 centímetros». «A sua cor é um tanto escura, sem vestígios de qualquer engobe que o faça realçar». «Campaniforme n. ${ }^{\circ} 2$ - Além do recipiente acima referido, há três fragmentos de uma outra vasilha do mesmo tipo (...). Levados pelo desenho e outros elementos, consideramo-los todos do mesmo recipiente (...). O fragmento da parte superior é de um bordo com decoração de linhas incisas praticadas com um utensílio de bico rombo, além de diversos reticulados de sulcos mais profundos. Os fragmentos da parte média e inferior, se bem que um tudo nada diferentes na decoração, parecem constituir elementos de partes diversas da mesma vasilha.

$\mathrm{O}$ primeiro fragmento apresenta ainda um ligeiro brunido tanto no interior como no exterior. O segundo contém vestígios de engobe nas duas faces. No terceiro ainda é visível o engobe exterior, bem como restos de uma matéria branca que em muito realçaria a decoração». Nas p. 98 e 99 fala das sementes dadas como perdidas por M. V. Natividade, ob. cit., e diz terem sido analisadas pelo Eng. Agrónomo A. R. Pinto da Silva, chefe do Departamento de Fitossiste- 
mática e Geobotánica da Estação Agronómica Nacional.

- Victor dos Santos Gonçalves, 1978, p. 15 defende que as cerámicas lisas desta gruta têm características megalíticas. Nas p. 16 e 17, descreve dez recipientes cerâmicos, muito embora tenha dúvidas sobre a proveniência exacta de alguns. Apresenta fotografias e desenhos. Comparando as suas descrições, desenhos e fotografias com os desenhos apresentados por Manuel Vieira NaTIVIDADE, ob. cit., estampa 21, pudemos identificar certos vasos como sendo realmente desta gruta. V. S. Gonçalves, p. 16, refere como o n. ${ }^{\circ} 878$ : «Um recipiente pouco fragmentado, corpo cilindroide, fundo plano. Altura total: 15,3 cm. Diâmetro de fundo: 11,5 cm. Espessura do bordo : $9 \mathrm{~mm}$. Cor cinzenta-escura. Desengordurantes de tamanho mínimo. Cerâmica grosseira, de cozedura redutora. Bordo de lados irregularmente paralelos terminando em superfícies de topo, planas». Pensamos ser o vaso desenhado por M. V. Natividade, ob. cit., estampa 21, n. ${ }^{\circ} 176$.

Aquele autor, p. 17, refere com o n. ${ }^{\circ} 892$ : «Recipiente ligeiramente fragmentado, de corpo esferoidal e colo estrangulado. Altura total: $11,7 \mathrm{~cm}$. Diâmetro interno da abertura: $7,3 \mathrm{~cm}$. Espessura de bordo: $6 \mathrm{~mm}$. Cozedura oxidante ( ?). Cor castanho-alaranjado. Desengordurantes de dimensões mínimas. Recipiente de colo estrangulado (...). Fundo convexo, sendo o equihbrio do vaso garantido pelo peso do recipiente». Trata-se do vaso desenhado por M. V. NATIVIDADE, ob. cit., estampa 21, n. $^{\circ} 179$.

Parece-nos que o vaso da estampa $27, \mathrm{n}^{\circ} 1$, identificado como do Carvalhal de Aljubarrota e o da estampa 28, n. $^{\circ} 1$, fotografados por V. S. Gonçalves, ob. cit., são os mesmos dese- 
nhados por M. V. NATIVIDAdE, ob. cit., na estampa 21 com os números 181 e 182, respectivamente, e pertencentes à gruta das Redondas.

- Octávio da Veiga Ferreira, 1982, p. 20, refere espolio osteológico e malacológico no armário n. ${ }^{\circ} 11$.

\subsection{IDADE DO BRONZE}

\subsubsection{Algar do Estreito ou Gruta do Carvalhal de Turquel}

Tipo de Est. - ver ficha 3.2.2.

Cl. Cron. - Bronze inicial ( ?).

Lug. $\quad$ - ver ficha 3.2.2.

Loe. Geog. - ver ficha 3.2.2 (fig. 1.5).

Geomorf. - ver ficha 3.2.2.

Esc. $\quad$ - ver ficha 3.2.2.

Desc. da Est. - ver ficha 3.2.2.

Esp. - Segundo K. Spindere e O. V. ferreira, ob. cit., as cerâmicas datáveis da Idade do Bronze por comparação com certas estações deste período, no Sudoeste da Península e em certas grutas da Estremadura, são as seguintes:

- 1 vaso cerâmico de fundo esférico e carena alta com asa de inserção lateral e preensão horizontal na parte superior. É decorado com motivos geométricos segundo a técnica de incisão e do pontilhado na parte superior do bojo entre $o$ bordo e a carena.

- 1 fragmento de um vaso de fundo plano ou plano-convexo, com uma fiada de mamilos na parte média ou inferior do corpo do vaso.

- 4 vasos lisos com carenas baixas e médias e fundos convexos.

- 3 vasos lisos tipo taça, de fundos planos e plano-convexos. 
- 1 vaso liso tipo taça, de fundo plano-convexo com estrangulamento na parte inferior do corpo do vaso. Poder-se-á eventualmente incluir na presumível fase a que pertencem os referidos materiais, o vaso campaniforme.

Dep. $\quad$ - Sala de Arqueologia Pré-Histórica do Museu dos Serviços Geológicos de Portugal (Lisboa), nas vitrinas centrais n. ${ }^{\text {os }} 65$ e 66 .

Bib. $\quad-$ Ver ficha 3.2.2.

\subsubsection{ARDIDO}

Tipo de est. Indeterminada.

Cl. Cron. - Bronze médio ( ?).

Lug. -Ardido.

Loc. Geog. C.M.P., esc. 1:25.000, 317 Alcobaça, M.126,7; P.280,8; Alt. 140 m. Levantamento de 1939/40 (fig. 1.8).

Geomorf. No alto da encosta Este da ribeira das Antas, num terreno agrícola.

Desc. da Est. -José Diogo Ribeiro, 1941, diz que o espólio metálico apareceu a pouca profundidade. Estes dados foram corroborados por informadores locais $\left(^{6}\right)$, que nos disseram ter aparecido o espólio a cerca de $1 \mathrm{~m}$. de profundidade, quando da abertura de um pequeno poço para retenção das águas da chuva.

Esp. $\quad 2$ braceletes de ouro e fragmentos cerâmicos.

Dep. - As peças metálicas encontram-se no Museu Nacional de Arqueologia e Etnologia (Lisboa) com os n. ${ }^{\text {os }}$ de inventário 177 e 178.

Bib. $\quad$ P. e M. Luís, 1935, p. 44, refere este achado.

$\left(^{6}\right)$ Informações orais prestadas por Francisco Rodrigues, morador no lugar do Ardido e que nos falou de «cacos velhos» associados às peças de ouro. 
- José Diogo Ribeiro, 1941, p. 7, diz: «No lugar do Ardido, povoação desta freguesia encontrou Artur Luís 2 argolas de oiro de imperfeito fabrico e que estavam enterradas a pouca profundidade».

- Tegouros da Arqueologia Portuguesa, 1980, p. 19, regista este achado.

\subsubsection{Boiça}

Tipo de Est. - Indeterminada.

Cl. Cron. - Bronze final/Ferro antigo (?).

Lug. - Turquel ( ?).

Loc. Geog. - Devido à impossibilidade de localizar o achado no terreno, referimos as coordenadas do antigo lugar de Boiça. G.M.P., esc. 1:25.000, 327 Turquel (Alcobaça), M. 126,5; P.278,9; Alt. entre 160 a 190 m. Levantamento de 1931/32 (fig. 1.9).

Geomorf. - A meio de uma encosta sobranceira ao rio das Antas, onde existem algumas chãs agrícolas.

Desc. da Est. - Desconhecida.

Esp. $\quad-$ «Sanguessugas» em ouro pesando 4,8 $\mathrm{g}$ e 4,6 g.

Dep. - Museu Nacional de Arqueologia e Etnologia (Lisboa) com os n. ${ }^{\text {ss }}$ de inv. 571 e 592.

Bib. - Tesouros da Arqueologia Portuguesa, 1980, p. 24, regista este achado.

\section{6--IDADE DO FERRO}

\subsubsection{Cancela dos Chães}

Tipo de Est. - Necrópole - Cistas com urnas cinerárias ( ?).

Cl. Cron. -Ferro antigo ( ?).

Lug. - Eiras ?

Loc. Geog. - Hipotética - C.M.P., esc. 1:25.000, 327 Turquel (Alcobaça) M.127,7; P.278,5; Alt. 190 m. Levantamento de 1931/32. Não conseguimos localizar a estação no terreno (fig. 1.10). 
Geomorf. —Segundo J. D. RibeIRo, 1908, a necrópole ficaria numa pequena chã com afloramentos calcários, em zona árida e seca com dois algares nas imediações.

Desc. da Est. - Várias sepulturas de forma rectangular, pequenas, cobertas de pedra ou com uma läge e pedra. Conhecemos descrições de 3 delas:

- 2 sepulturas rectangulares de grés amarelado não oriundo do local, com cerca de $1 \mathrm{~m}$ de comprimento por $0,5 \mathrm{~m}$ de largura e $0,5 \mathrm{~m}$ de profundidade. Eram cobertas por uma camada de terra de 20 a $30 \mathrm{~cm}$ de espessura e estavam orientadas no sentido Norte-Sul.

- 1 sepultura com cerca de 3 palmos de comprimento (i $70 \mathrm{~cm}$ ) e 2 de largura (i $40 \mathrm{~cm}$ ).

Esp. - - $\quad$ Segundo J. D. Ribeiro 1908; 1930; 1935, quase todas tinham espólio cerâmico e ossos pequenos e desfeitos misturados com cinzas. Espólio das duas primeiras sepulturas descritas.

\section{- Cerâmico:}

Fragmentos de grandes vasos de barro.

\section{- Metálico:}

1 anel ( ?) de cobre ( ?), várias argolas de diversas dimensões em bronze, 1 conta em bronze, 1 estilete ou furador em bronze e 1 brinco (?).

\section{Osteológico:}

muitos fragmentos ósseos de pequenas dimensões, entre os quais 1 fragmento de costela humana, misturados com cinzas e carvões muito esponjosos.

Dep. Museu Vieira Natividade (Alcobaça).

Bib. José Diogo Ribeiro, 1908, p. 19 e 20, refere: «Descobriram-se ha annos na Cancella dos Chães, a pouco mais de 1 kilómetro de Turquel para nornordeste, duas sepulturas do período do 
bronze (...). Longitudinalmente, orientados segundo a linha norte-sul, estas sepulturas tinham cerca de um metro de complimento, meio metro de largo e outro tanto de profundidade, não havendo nellas outra cobertura (ao menos na actualidade) além da camada de terra, de uns vinte a trinta centímetros de espessura que lhes sobrepujava os bordos.

Nestas sepulturas acharam-se grandes vasos de barro, fragmentados - muitas partículas de osso, das quais apenas me foi possível reconhecer parte de uma costella, - algumas argolas metálicas, de várias grossuras e diametros, uma das quaes do tamanho e fórma de um annel, me pareceu de cobre, e as outras, maiores e mais grossas, de bronze, - uma arrecada e uma pequena conta, também de bronze, - um como estylete ou furador, da mesma materia, - e alguns pedacinhos de um carvão muito leve e esponjoso. A pedra utilizada na construção d'estas caixas mortuárias, foi o grés amarellado conhecido pela designação vulgar de pedra broeira, - rocha não oriunda do sítio, e que portanto houve de ser para ah transportada expressamente». Apresenta fotografia da arrecada (?) de bronze na pág. 21.

— José Diogo Ribeiro, 1930, p. 11 refere: «(...) outras (sepulturas) se têm aí encontrado, todas de pequenas dimensões e em forma de caixa sem fundo (1). Cobria-as uma läge sobrepujada de cascalho, ou apenas cascalho. Incluíam quase todas, vasos de barro». Em nota de rodapé acrescenta: «(1) Uma que vi tinha cérca de 3 palmos de comprimento e 2 de largura».

- José Diogo Ribeiro, 1935, p. 42, refere o achado das 2 sepulturas aqui descritas e fala de outras de forma sumária: «(...) nas demais só se acharam ossadas meio desfeitas e também, nalgumas, vasos de barro». 


\section{7 ÉPOCA ROMANA}

\subsubsection{Lombo Ferreiro}

Tipo de Est. - Indeterminada.

Cl. Cron. - Indeterminada.

Lug. - Chão do Galego ou Poço das Vinhas.

Loc. Geog. - C.M.P., esc. 1:25.000, 317 Alcobaça, M.127,8; P. 280; Alt. cerca de $170 \mathrm{~m}$. Levantamento de 1939/40. Esta é a localização do esporão (fig. 1.11). Nas cercanias, têm aparecido outras zonas com vestígios arqueológicos à superfície e que, pela sua proximidade e pela natureza dos vestígios, parecem estar relacionadas com a primeira. Resolvemos cartografá-las. C.M.P., esc. 1:25.000 327 Turquel (Alcobaça), M.128 e 128,3; P.279,8 e 280 respectivamente. Alt. entre 180 e $190 \mathrm{~m}$. Levantamento de 1931/32 (fig. 1.12 e 13).

Geomorf. - Primeira zona: numa plataforma em esporão formado por calcários do Jurássico superior onde se sobrepõem terrenos agrícolas. Tem condições naturais de defesa em todos os quadrantes com excepção do Sudeste e Este, onde aparecem os outros vestígios cartografados — segunda e terceira zonas.

Desc. da Est. - As três zonas parecem pertencer à mesma estação pela sua proximidade e pela semelhança do espólio encontrado. No esporão, na primeira zona cartografada, ainda se encontram restos de muros feitos de cantaria, mas que, devido às grandes alterações e destruições a que foram sujeitos, não definem formas concretas. Num muro de propriedade que passa perto destas estruturas foram reutilizadas pedras aparelhadas provenientes das antigas construções. Segundo 
fontes orais, é esta a zona onde apareceu escoria em grande quantidade $\left({ }^{7}\right)$.

Os alicerces de habitação circulares ou ovais e fundamentos de pedra e cal, cantaria e pavimento argamassados que José Diogo Ribeiro, 1908, regista, deviam encontrar-se neste local. $\mathrm{Na}$ segunda zona cartografada não há estruturas visíveis e os materiais aparecem à superfície muito dispersos. Na terceira, os vestígios espalham-se em grande profusão numa pequena área de $40 \mathrm{~m}^{2}$ onde o terreno é ligeiramente mais elevado e de outra coloração — castanho mais escuro.

Esp.

\section{Primeira zona}

Não detectámos nada à superfície pois os terrenos encontram-se cobertos de vegetação. No entanto, J. D. Ribeiro, 1908; 1935; regista espólio que cremos ser proveniente deste local.

- Cerâmico:

fragmentos de grandes vasos; mós de pequenas dimensões; pesos de tear; fragmentos de telhas e tijolos.

- Metálico:

escória de ferro e moedas de cobre e bronze.

- Litico:

calhaus rolados.

- Conchífero:

conchas de ostras.

2 Segunda zona:

- Cerâmico:

fragmentos de «tegulae» e «lateres»; cerâmica comum e 1 peso de tear (fig. 6 e 7).

(7) Informação oral prestada por José Pereira Ribeiro, morador no Zambujeiro. 


\section{- Metálico}

1 escopro de ferro de grandes dimensões, muito alterado e um fragmento de urna placa perfurada em ferro.

\section{- Conchífero}

conchas de ostras.

\section{Terceira zona:}

\section{- Cerámica:}

grande quantidade de «imbrices» ( ?), algumas com marcas de dedadas; 1 tijolo de coluna, triangular; fragmentos de cerâmica comum, alguns de pasta negra com características muito arcaizantes. Nenhum destes elementos pode ser considerado com segurança do período romano.

Dep. $\quad-1-$ Desconhecido; 2 e 3 - Instituto de Arqueologia da Fac. de Letras da Univ. de Coimbra.

Bib. - Manuel Vieira Natividade, 1906, p. 52, refere a abundância de elementos metalúrgicos num local designado por Lombo Ferreiro.

— José Diogo Ribeiro, 1908, p. 27, em nota de rodapé refere: «Casas ou curraes de forma approximadamente redonda ou oval e de que restam alicerces, houve bastantes nas cercanias do Lombo Ferreiro». Na p. 164 descreve as estruturas visíveis e o espólio. «(...), moedas de cobre (duas que vi eram romanas) (...)».

- José Diogo Ribeiro, 1935, p. 42, refere: «No aludido Lombo, que parece corresponder ao local dum antigo estabelecimento metalúrgico, têm aparecido algumas moedas romanas de bronze». 


\section{Conclusão}

Apesar do pequeno número de estações referenciadas, a análise atenta das condições de jazida e do espólio permitiu-nos tirar conclusões sobre a natureza dessas mesmas estações e acertar alguns dados confusos provenientes de publicações antigas. Por outro lado, o trabalho de localização no terreno e de cartografia de cada uma dessas estações levou-nos a verificar tendências na distribuição da população no espaço.

- Verificamos que a ocupação pré-histórica, embora efectiva em toda a área da freguesia, parece concentrar-se na zona do grande vale ocidental da serra dos Candeeiros e nas duas encostas que o delimitam. As características geomorfológicas da encosta, em cujos calcários se formaram abundantes grutas, foram, sem dúvida, um factor importante na ocupação desta área.

- A proximidade do mar, actualmente a cerca de 20 quilómetros em linha recta (mais uma fonte de recurso alimentar), a proximidade de jazidas de matérias-primas como sílex, a cerca de 18 quilómetros (Pederneira - Nazaré) e os bancos de argila que se formam na encosta da serra são, possivelmente, outros factores a ter em conta na distribuição da população, quer no vale quer em toda a zona. Faltam-nos, no entanto, estudos pluridisciplinares e um trabalho de prospecção sistemática de âmbito alargado para que possamos confirmar e/ou generalizar as nossas hipóteses de trabalho a toda a região.

- O âmbito cronológico dos vestígios arqueológicos é lato; o povoamento parece remontar ao Paleolítico, se não ao Inferior, pelo menos ao Superior, e apesar da «falta» aparente de elementos atribuíveis ao Mesolitico, ele deve ter-se estendido sem interrupções até à época romana.

- É de salientar a descoberta do monumento das Fontes Velas 1, inédito, que junto com dados de ordem bibliográfica (Anta da Barbata e Pedras d'Antas), orais (Fontes Velas 2) e toponímicos (ribeira das Antas e lugar das Antas, já na freguesia de Évora de Alcobaça), provam de forma 
indiscutível a presença do fenómeno megalítico na sua dimensão arquitectural nesta região. Esta é, quanto a nós, a novidade mais importante deste trabalho, pois demonstra que o «megalitismo de grutas» defendido por Victor dos Santos Gonçalves, 1978a); 1978b) não impediu outras formas de expressão desse fenómeno nesta região.

- A presença de uma necrópole de cistas com urnas funerárias, pouco frequente ou raramente identificada, no território português, e que nos parece ter sido completamente destruída, é mais um caso que nos alerta para a necessidade de um projecto de investigação sistemática na região. 


\section{BIBLIOGRAFIA}

Aberg, Nils (1921), La Civilisation Enéolithique dans la Péninsule Ibérique, Paris.

Azevedo, Pedro A. de (1903), Extractos Archeologicos das «Memorias Parochiaes de 1755» Turquel [Gruta), in «Archeologo Portugués», 1. ${ }^{\mathrm{a}}$ série, vol. 8, Lisboa, p. 257-258.

Cardoso, J. Carvalho; Bessa, M. Teixeira; Marado, M. Branco(1971), Canados Solos de Portugal, esc. 1:1000.000, in "Agronomia Lusitana», vol. 33, T. 1-4, p. 481-602.

Cartailhac, Emile (1886), Les Ages Pré-Historiques de VEspagne et du Portugal, Paris.

Ferreira, Denise de Brum (1981) - Carte Geomorphologique du Portugal, Memórias do Centro de Estudos Geográficos, n. ${ }^{\circ}$ 6, Lisboa.

Ferreira, Octávio da Veiga (1964), Jazidas Quaternárias com Fauna de Vertebrados Encontrados em Portugal, in «Arqueologia e História», Lisboa, 8. ${ }^{\mathrm{a}}$ série, $\mathrm{n} .^{\circ} 11$, p. 37-53.

Ferreira, Octávio da Veiga (1982), Guia Descritiva da Sala de Arqueologia Pré-Histórica, Museu Geológico Nacional, Lisboa.

Ficha Manuscrita (1880?), Bala de Arqueologia Pré-Histórica do Museu dos Serviços Geológicos de Portugal, armário central n. 34 - gavetas.

Figueiredo, A. Mesquita de (1895), Informações Archeológicas Colhidas no «Diccionário Geográfico» de Cardoso. Gruta de Albardos [Estremadura), in «Archeòlogo Português», 1. a série, vol. 1, Lisboa, p. 154.

França, J. Camarate (1950), A Vasilha Zoomórfica da Gruta do Carvalhal [Turquel), in «Mensário Administrativo», n. ${ }^{\text {s }} 39-40$, Luanda, p. 95-98.

França, J. Camarate; Zbyszewsini, G. (1963), Carta Geológica de Portugal na Escala 1/50.000. Notícia Explicativa da folha 26-B Alcobaça, Lisboa.

Gonçalves, Victor dos Santos (1978a), Para um Programa do Estudo do Neolítico em Portugal, in «Zephyrus», n. ${ }^{\circ} 28-29$, Salamanca, p. 147-162.

Gonçalves, Victor dos Santos (1978b), A Neolitização e o Megalitismo da Região de Alcobaça, Lisboa.

Ha RLÉ, Edouard (1910/1911), Les Mammifères et Oiseaux Quaternaires Connus Jusqu ici en Portugal, in «Com. dos Serv. Geol. de Port.», t. 8, Lisboa, p. 22-86.

Leal, Augusto S. A. B. de Pinho (1873), Albardos ou Alvados, in Portugal Antigo e Moderno, vol. 1, p. 46-48.

Luis (?), P. M. (1935), Turquel, no Passado e no Presente, in «Jornal Ecos do Alcoa», número especial, 15 de Agosto, Alcobaça, p. 44.

Natividade, Manuel Vieira (1885), O Mosteiro de Alcobaça [Notas Históricas), Coimbra.

Natividade, Manuel Vieira (1899/1903), As Grutas de Alcobaça, in «Portugália», t. 1, fase. 3, Porto, p. 433-474.

Conimbriga, 27 (1988), 153-188 
Natividade, Manuel Vieira (1906), Alcobaça d'Outro Tempo, Alcobaça.

Paço, Afonso do (1966), As Grutas de Alcobaça-Aditamento, in «Zephyrus», vol. 17, Salamanca, p. 89-99.

Ribeiro, José Diogo (1908), Memorias de Turquel, Porto.

Ribeiro, José Diogo (1927/1934), Turquel Folclórico (Superstições, Usos e Costumes), Esposende, 6 vol.

Ri beiro, José Diogo (1930), Aditamento às Memórias de Turquel, Braga.

Ribeiro, José Diogo (1935), Turquel (Notícia Histórico-Tópográfica), in «Jornal Ecos do Alcoa», número especial, 15 de Agosto, Alcobaça, p. 42.

Ri B E Iro, José Diogo (1941), 2. ${ }^{\circ}$ Aditamento às Memórias de Turquel, Leiria.

Silva, Carlos da; Silva, Alberto Eduardo Nogueira de Alarcão e (1961), A Região a Oeste da Serra dos Candeeiros. Estudo Económico-Agrícola dos Concelhos de Alcobaça, Nazaré, Caldas de Rainha, Óbidos e Peniche, Lisboa.

S Pinder , Konrad; Ferreira, Octávio da Veiga (1974), Das Vorgeschichtliche Fundmaterial aus der Gruta do Carvalhal, Portugal, in «Madrider Mitteilungen», n. ${ }^{\circ} 15$, Madrid, p. 28 a 76.

Tesouros da Arqueología Portuguesa (1980), Museu Nacional de Arqueologia e Etnologia, Lisboa.

Zвуszewsкy, Georges (1943), Les Eléphants Quaternaires du Portugal, in «Com. dos Serv. Geol. de Port.», T. 24, Lisboa, p. 71-93.

Zbyszewsky, Georges; Almeida, F. Moitinho (1960), Carta Geologica de Portugal na Escala 1/50.000. Notícia Explicativa da folha 26-D Caldas da Rainha, Lisboa. 


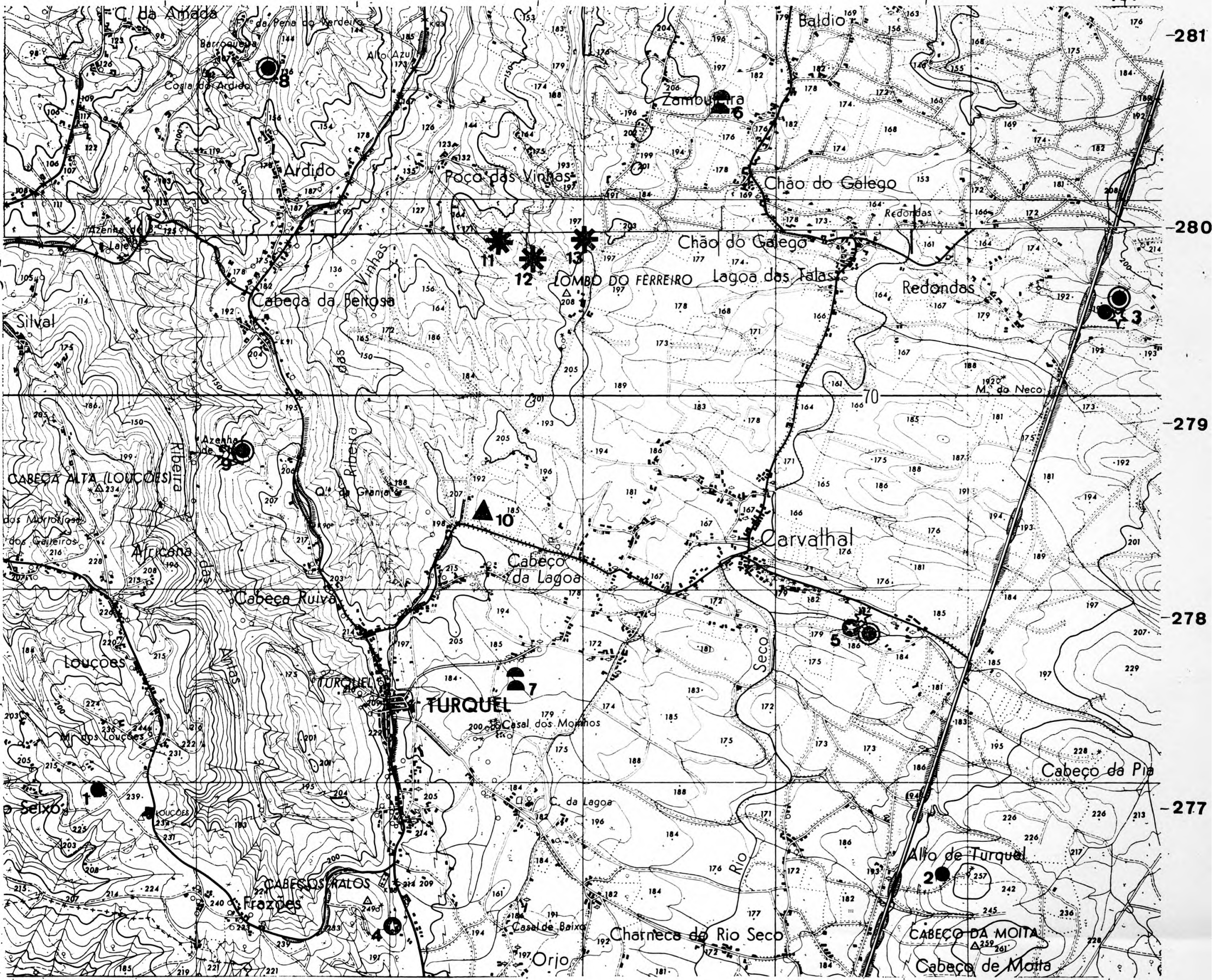

Fig. 1-Localização geográfica das estações referenciadas na C.M.P., esc. 1.25.000

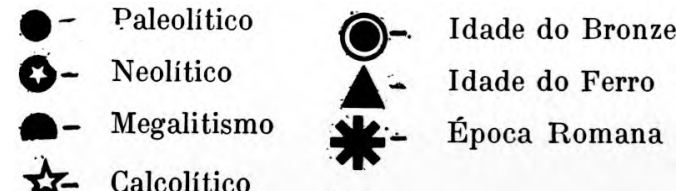


(Página deixada propositadamente em branco) 

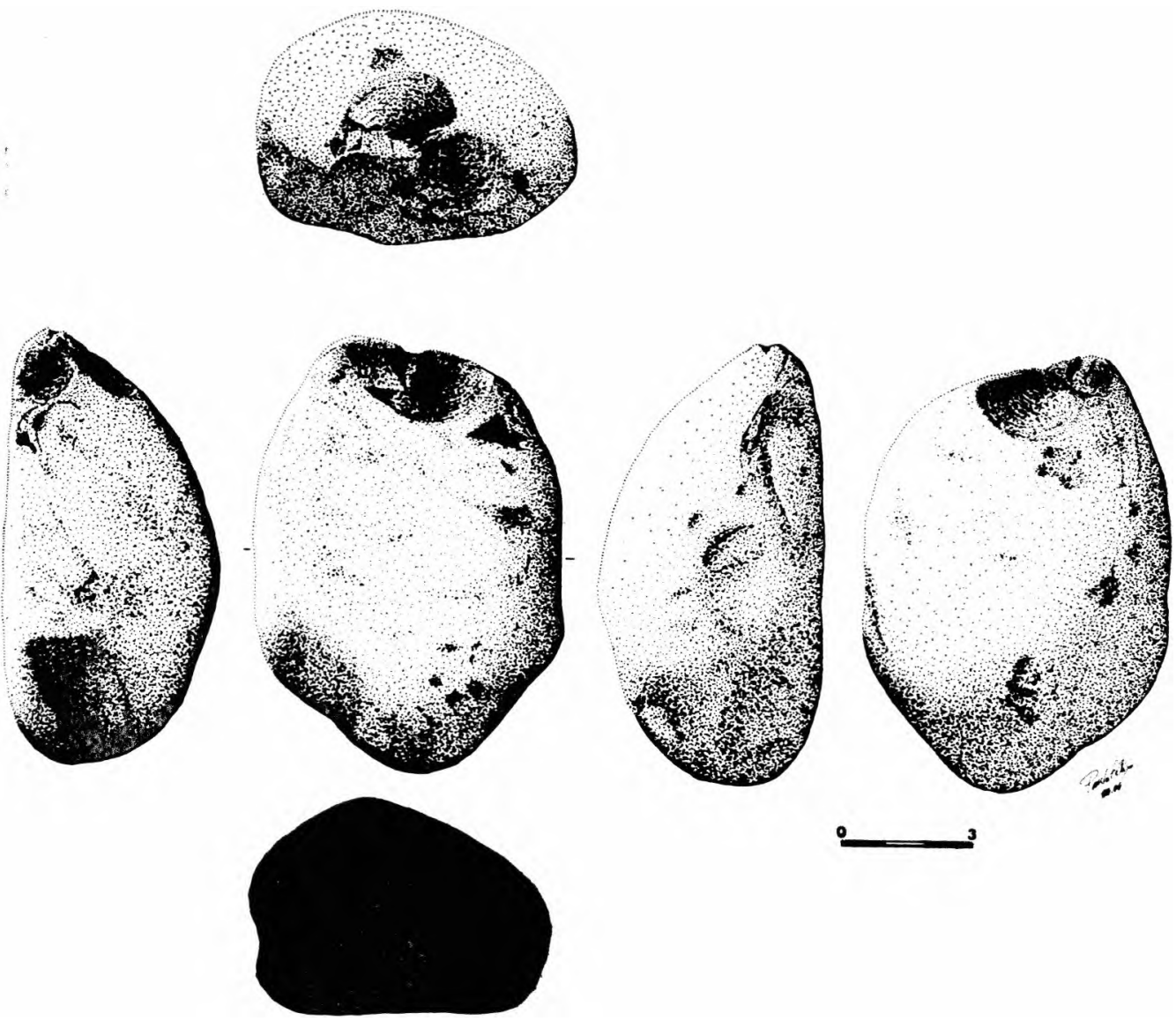

FIG. 2 


$$
232
$$



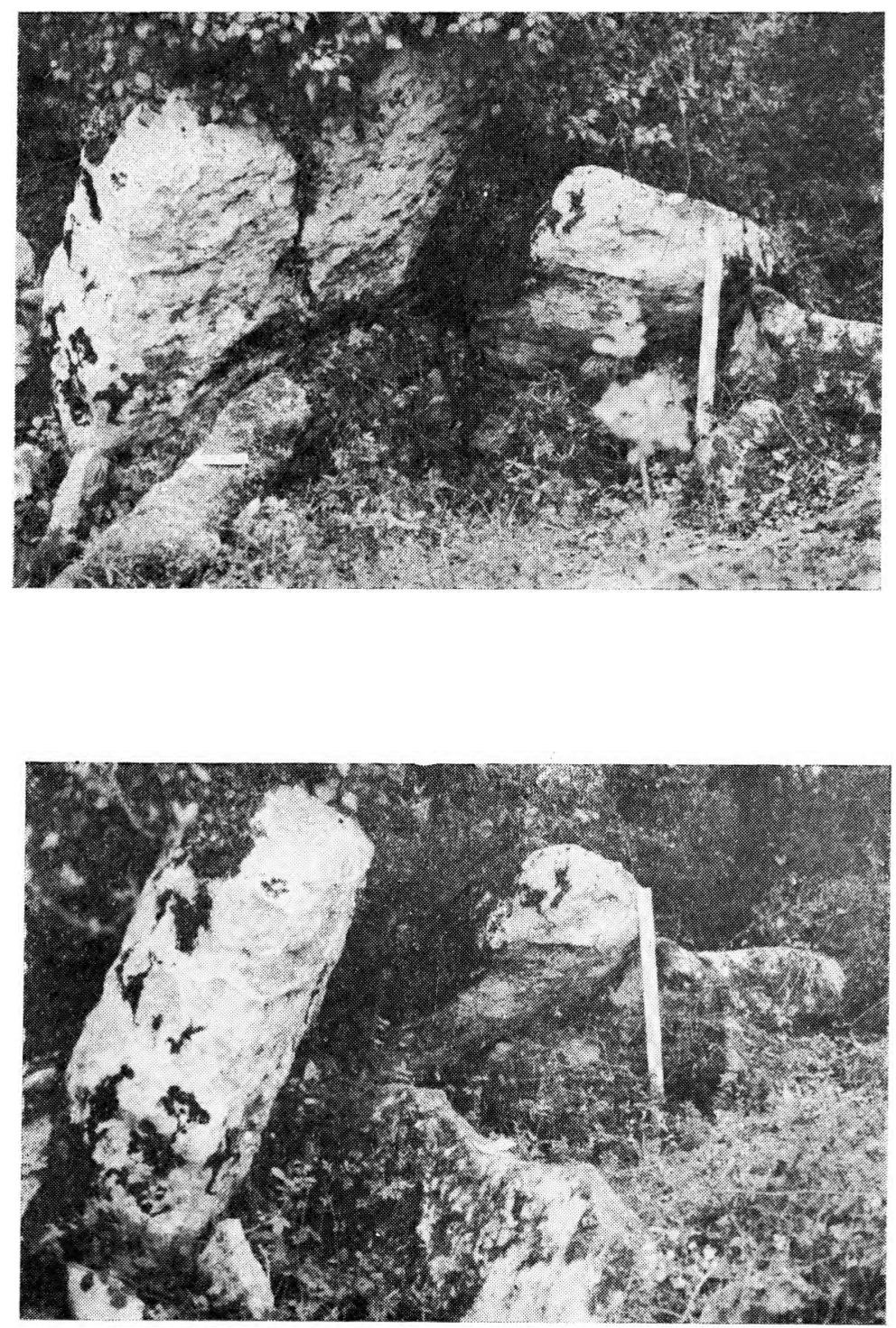

Fig. 4 - Mamoa 1 de Fontes Velas.

4.1 - Vista Este da câmara.

4.2 - Vista Sudeste da câmara 


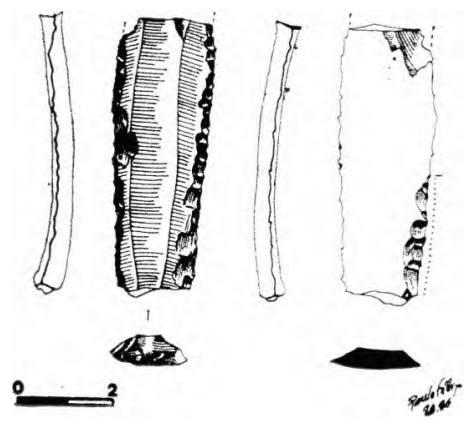

FIG. 5 


$$
3
$$




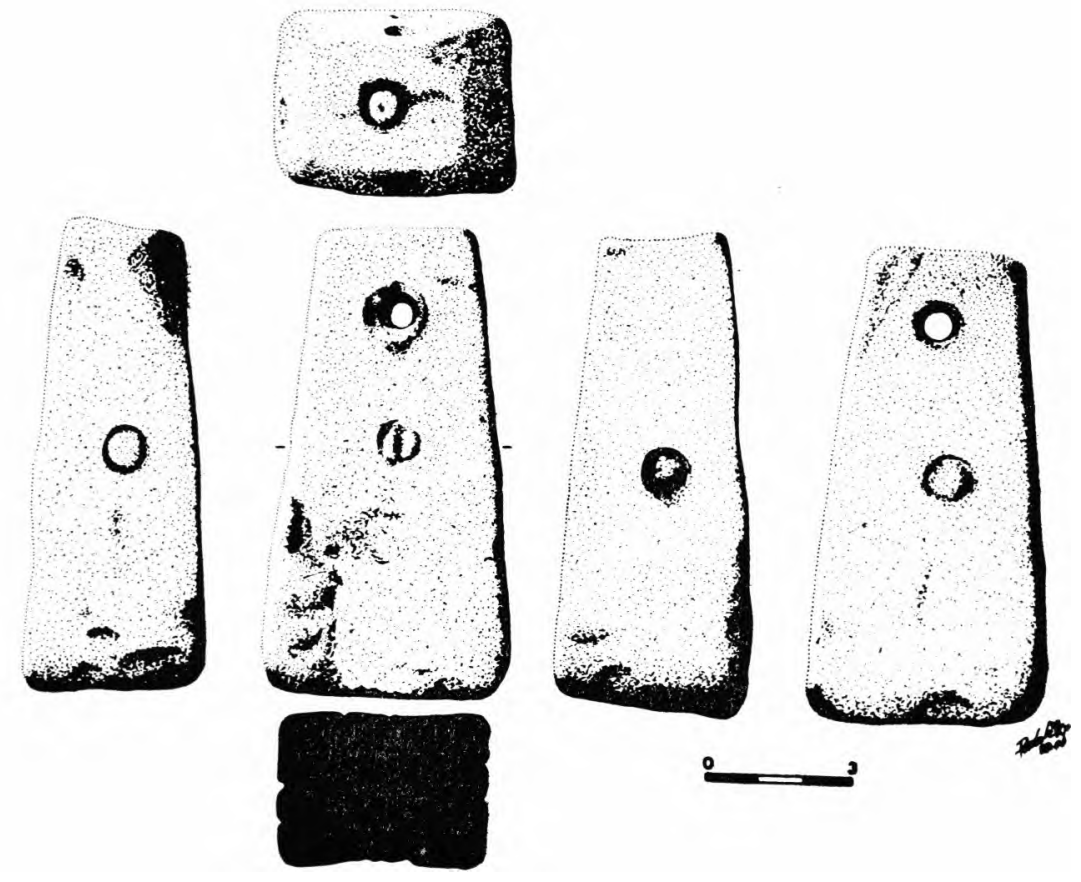

FIG. 7 